\title{
The development of a loop-mediated isothermal amplification assay for rapid and sensitive detection of abalone herpesvirus DNA
}

\author{
M.H. Chen ${ }^{\mathrm{a}, \mathrm{c}}$, S.T. Kuo ${ }^{\mathrm{b}}$, T. Renault ${ }^{\mathrm{d}}$, P.H. Chang ${ }^{\mathrm{a}, *}$ \\ a Institute of Veterinary Medicine, School of Veterinary Medicine, National Taiwan University, Taipei, Taiwan \\ ${ }^{\mathrm{b}}$ National Institute for Animal Health, Tansui, Taiwan \\ c Tzu Chi College of Technology, Hualien, Taiwan \\ d Ifremer, Unité Santé Génétique et Microbiologie des Mollusques, Laboratoire de Génétique et Pathologie des Mollusques Marins, 17390 La Tremblade, \\ France
}

\section{Article history:}

Received 17 July 2013

Received in revised form

16 November 2013

Accepted 20 November 2013

Available online 27 November 2013

\section{Keywords:}

Herpesvirus

Abalone

Haliotis diversicolor supertexta

Polymerase chain reaction

Loop-mediated isothermal amplification

SYBR green PCR

\begin{abstract}
A B S T R A C T
A loop-mediated isothermal amplification (LAMP) assay was developed for the detection of abalone herpesvirus DNA. Two pairs of primers were designed, based on the sequence of the DNA polymerase gene of abalone herpesvirus. The reaction temperature and time were optimized to $63^{\circ} \mathrm{C}$ and $60 \mathrm{~min}$, respectively. LAMP amplicons were analyzed by $2 \%$ agarose gel electrophoresis or by visual inspection of a colour change emitted by fluorescent dye. The method developed was specific for the detection of abalone herpesvirus, without cross-reactions with other tested herpesviruses including ostreid herpesvirus 1 (OsHV-1), European eel herpesvirus, koi herpesvirus (KHV) and an avian herpesvirus. The LAMP assay was 100 folds more sensitive than a conventional PCR and 10 folds less sensitive than a SYBR Green PCR. These results indicate that the developed LAMP assay is a simple, rapid, sensitive, specific and reliable technique for the detection of abalone herpesvirus.
\end{abstract}

(C) 2013 Elsevier B.V. All rights reserved.

\section{Introduction}

Herpesvirus infections have been reported in marine molluscs and a wide host range was reported in bivalves including various species of oysters, clams and scallops (Farley et al., 1972; Burge et al., 2011; Renault and Novoa, 2004; Renault, 2008). Mortality outbreaks of abalone (genus Haliotis) associated with herpes-like viruses have been reported in several species and subspecies including $H$. discus discus, $H$. discus hannai, $H$. diversicolor Reeve, $H$. diversicolor aquatilis, and $H$. diversicolor supertexta (Nakatsugawa et al., 1999; Otsu and Sasaki, 1997; Song et al., 2000; Wang and Li, 1997; Wang et al., 2000; Zhang et al., 2001). Acute and high mortality events due to herpesvirus, Haliotis herpesvirus (AbHV) were reported in cultured abalone, $H$. diversicolor supertexta, in Taiwan (Chang et al., 2005). A herpesvirus identified as Haliotis herpesvirus 1 (AbHV-1) induced mortality in blacklip abalone, $H$. rubra, greenlip abalone, $H$. laeviga, and their hybrids in Australia (Hooper et al., 2007). Although Australian abalone infected with AbHV-1 showed a swollen mouth and prolapsed odontophore (Hooper et al., 2007),

\footnotetext{
* Corresponding author. Tel.: +8862 33661296; fax: +886223661475.

E-mail address: penheng@ntu.edu.tw (P.H. Chang).
}

AbHV infection in Taiwanese abalone was characterized by mantle recession and muscle atrophy (Chang et al., 2005) without oral lesions. AbHV was a neurotropic virus causing ganglioneuritis, with necrosis of the cerebral ganglia and nerve bundles in the foot muscle and in muscular layers beneath the visceral organs (Chang et al., 2005). Similar neurological signs were also noted as ganglioneuritis in the blacklip abalone and greenlip abalone in Australia (Hooper et al., 2007). Another virus was also reported in the Japanese black abalone, $H$. (=Nordotis) discus associated with amyotrophia and tumour-like lesions in the nerve trunk (Nakatsugawa et al., 1999).

Light microscopy has been used to diagnose both AbHV and AbHV-1 infections based on the prominent neurological lesions induced by these viruses in Taiwan and Australia, respectively (Chang et al., 2005; Hooper et al., 2007). Additional techniques such as transmission electron microscopy, a TaqMan ${ }^{\circledR}$ PCR-based technique (Corbeil et al., 2010) and a classical PCR technique (Chen et al., 2012) have also been developed to detect herpesvirus infections in abalone.

The loop-mediated isothermal amplification (LAMP) procedure amplifies nucleic acids with high specificity, sensitivity and rapidity under isothermal conditions. This technique has been used for detecting various pathogens including E. coli 0157:H7 (Maruyama et al., 2003), Edwardsiella tarda in fish and environmental samples 
(Savan et al., 2004), Francisella piscicida in Atlantic cod (Caipang et al., 2010), white spot syndrome virus in shrimp (Kono et al., 2004), infectious hematopoietic necrosis virus (IHNV) in rainbow trout (Gunimaladevi et al., 2005), Koi herpesvirus (KHV) (Gunimaladevi et al., 2004; Soliman and El-Matbouli, 2005;), AVNV in Chinese scallops, Chlamys farireri (Weicheng et al., 2010) and iridovirus in fish (Caipang et al., 2004).

In this study, a LAMP assay for AbHV detection in abalone was developed following cloning and sequencing of the DNA polymerase gene from AbHV specimens from Taiwan (Chen et al., 2012). Based on the sequence of the DNA polymerase, four distinct primers were designed. Comparison of the LAMP, PCR and SYBR Green PCR techniques was performed to define detection limits for each technique.

\section{Materials and methods}

\subsection{Samples and DNA extraction}

Ten AbHV-infected abalone, $H$. diversicolor supertexta, were collected from six farms that suffered from either high or low mortalities in 2004 in northern Taiwan, and used as the material source. Twenty abalone collected from farms in southern Taiwan with no history of AbHV infection were used as negative controls. Nerve tissues of moribund abalone collected from one batch of the AbHV-affected farms were excised and held at $-80^{\circ} \mathrm{C}$ until DNA extraction. Nerve tissues of control abalone were also similarly excised and stored. DNA was extracted from nerve tissues using a QIAamp Stool Mini Kit (QIAgen, Hilden, Germany) following the manufacturer's instructions.

\subsection{LAMP primers}

Primer sets for LAMP were designed from Abalone herpesvirus DNA polymerase gene (GenBank accession no. HQ317456.1) using PrimerExplorer V4 software (http://primerexplorer.jp/elamp4.0.0/index.html). The primer sets consisted of two outer primers F3 and B3 (Table 1) and two inner primers FIP $5^{\prime}$ and BIP $5^{\prime}$ (Table 1 ) targeting a conserved region within the DNA polymerase gene, with expected $198 \mathrm{bp}$ amplified product.

\subsection{LAMP conditions}

AbHV DNA extracted from purified virus particles was used as the template (Chen et al., 2012) using the commercial Loopamp DNA Amplification kit (Eiken) that followed the LAMP procedure of Notomi et al. (2000). Briefly, a total reaction of $23 \mu \mathrm{L}$ per test contained $12.5 \mu \mathrm{l}$ of $40 \mathrm{mM} 2 \times$ Reaction Mix (Tris- $\mathrm{HCl}(\mathrm{pH} 8.8$ ), $20 \mathrm{mM} \mathrm{KCl}, 16 \mathrm{mM} \mathrm{MgSO}_{4}, 20 \mathrm{mM}\left(\mathrm{NH}_{4}\right)_{2} \mathrm{SO}_{4}, 0.2 \%$ Tween, $1.6 \mathrm{M}$ Betaine, 2.8 mM dNTPs), 40 pmol FIP, 40 pmol BIP, 5 pmol F3, 5 pmol B3, $1.0 \mu \mathrm{L}$ Bst DNA Polymerase, and $100 \mathrm{ng}$ of template genomic DNA, and was brought up to volume with sterile distilled water. All reagents except primers were applied to the control reaction. The LAMP was carried out at $60-65^{\circ} \mathrm{C}$ at $1{ }^{\circ} \mathrm{C}$ interval each for $15 \mathrm{~min}$, $30 \mathrm{~min}, 45 \mathrm{~min}$ and $60 \mathrm{~min}$. Amplicons were analyzed by $2 \%(\mathrm{w} / \mathrm{v})$ agarose gel electrophoresis and stained with ethidium bromide.

\subsection{Specificity of the AbHV LAMP assay}

To determine the specificity of the LAMP assay, eel herpesvirus DNA, koi herpesvirus DNA, avian infectious laryngotracheitis virus DNA and OsHV-1 DNA were tested and products were analyzed on a $2 \%(w / v)$ agarose gel.

\subsection{Sensitivity and detection limits of LAMP, conventional PCR and SYBR Green PCR}

The sensitivity of the LAMP assay was assessed using cloned AbHV DNA. The primer set B3 and 1331r (Table 1) were designed to amplify an expected product of $1202 \mathrm{bp}$ from the AbHV DNA polymerase gene. PCR amplification was performed as described by Chen et al. (2012). Primers 40 f and $146 \mathrm{r}$ (Table 1 ) were designed to amplify an expected product of $606 \mathrm{bp}$. A total of $50 \mu \mathrm{l}$ reaction mixture contained $5 \mu \mathrm{l}$ of $10 \times$ PCR buffer $(10 \mathrm{mM}$ Tris- $\mathrm{HCl}, 50 \mathrm{mM}$ $\mathrm{KCl}, 1.5 \mathrm{mM} \mathrm{MgCl}_{2}$, and $0.001 \%$ (w/v) gelatin), $400 \mu \mathrm{M} \mathrm{dNTPs,} 5 \mu \mathrm{M}$ tetramethylammonium chloride, 40 pmol of each primer, $2 \mu \mathrm{L}$ purified DNA and $2 \mathrm{U}$ of Taq polymerase, and brought up to volume with sterile distilled water. PCR amplification was performed in a PTC100 thermocycler (MJ Research, Alameda, CA, USA) with an initial denaturation step at $94^{\circ} \mathrm{C}$ for $2 \mathrm{~min}$; followed by 35 cycles of $1 \mathrm{~min}$ at $94{ }^{\circ} \mathrm{C}, 1 \mathrm{~min}$ at $52^{\circ} \mathrm{C}$ and $1 \mathrm{~min}$ at $72^{\circ} \mathrm{C}$; and finally by incubation for 5 min at $72^{\circ} \mathrm{C}$. A control PCR without template was used to check cross-contamination. All reactions were carried out in triplicate. Amplified fragments were electrophoresed in 1\% agarose gels and visualized with UV illumination after staining with ethidium bromide.

Table 1

Oligonucleotide primer sets used for the LAMP, PCR and SYBR Green PCR.

\begin{tabular}{|c|c|c|c|c|c|}
\hline Method & $\begin{array}{l}\text { Primer } \\
\text { name }\end{array}$ & Genome position $^{\mathrm{a}}$ & Type & Sequence $\left(5^{\prime}-3^{\prime}\right)$ & $\begin{array}{l}\text { Expected size } \\
\text { of product (bp) }\end{array}$ \\
\hline LAMP & $\begin{array}{l}\text { F3 } \\
\text { B3 } \\
\text { FIP }^{\mathrm{b}} \\
\text { BIP }^{\mathrm{b}} \\
\text { F2 } \\
\text { F1c } \\
\text { B2 } \\
\text { B1c }\end{array}$ & $\begin{array}{l}5059-5076 \\
5237-5256 \\
(\mathrm{~F} 1 \mathrm{c}+\mathrm{F} 2) \\
(\mathrm{B} 1 \mathrm{c}+\mathrm{B} 2)\end{array}$ & $\begin{array}{l}\text { Forward outer } \\
\text { Backward outer } \\
\text { Forward inner } \\
\text { Backward inner }\end{array}$ & $\begin{array}{l}\text { AGCAACGCCAAGAACAGG } \\
\text { TCGTTCTCCGAACATCCACT } \\
\text { GGAGCGAAGGAAGCCACTTCTTTTCTTTCAAAGCGGAGTGCG } \\
\text { ATTCCGGGCAAGTCTGCAGTGCTTGTCGTCCCTGATGAAC } \\
\text { TTCTTTCAAAGCGGAGTGCG } \\
\text { GGAGCGAAGGAAGCCACTTCTT } \\
\text { GCTTGTCGTCCCTGATGAAC } \\
\text { ATTCCGGGCAAGTCTGCAGT }\end{array}$ & 198 \\
\hline Real time PCR & $\begin{array}{l}\text { F3 } \\
\text { B3 }\end{array}$ & $\begin{array}{l}5059-5076 \\
5237-5256\end{array}$ & & $\begin{array}{l}\text { AGCAACGCCAAGAACAGG } \\
\text { TCGTTCTCCGAACATCCACT }\end{array}$ & 198 \\
\hline Cloning & $\begin{array}{l}\text { B3 } \\
1331 r\end{array}$ & $\begin{array}{l}5237-5256 \\
4055-4074\end{array}$ & & $\begin{array}{l}\text { TCGTTCTCCGAACATCCACT } \\
\text { CTCGCGAAAAGGTAAACAGC }\end{array}$ & 1202 \\
\hline PCR & $\begin{array}{l}381 \mathrm{f} \\
864 \mathrm{r}\end{array}$ & $\begin{array}{l}4435-4918 \\
4899-4918\end{array}$ & & $\begin{array}{l}\text { TCGTTCTCCGAACATCCACT } \\
\text { CGTCGTTACCCAGTTCCACT' }\end{array}$ & 484 \\
\hline
\end{tabular}

\footnotetext{
a Genome target region based on the nucleotide sequence of the polymerase gene of AbHV (GenBank accession no. HQ317456.1).
}

b Both inner primers FIP and BIP contained two binding regions and were connected by a TTTT bridge. 
The PCR product was ligated into the TA cloning vector and transformed into competent $E$. coli cells following procedures described by the manufacturer. The concentration of the recombinant plasmid was determined by Nanodrop 2000c (Thermo Scientific, USA) and used to prepare serial dilutions. The plasmid DNA of AbHV was diluted $\left(2 \times 10^{-1}-2 \times 10^{-8}\right.$ copies per $\left.\mu \mathrm{L}\right)$ in Tris-EDTA buffer ( $10 \mathrm{mM}$ Tris, $1 \mathrm{mM}$ EDTA, pH 8.0, TE) and used as template DNA in optimizing the LAMP reaction. A conventional PCR was performed with the same template DNA using the primer set $381 \mathrm{f}$ and $864 \mathrm{r}$ to amplify a $484 \mathrm{bp}$ fragment with similar reaction conditions to those stated in Section 2.5. LAMP and PCR products were electrophoresed on a $2 \%(\mathrm{w} / \mathrm{v})$ agarose gel and stained with ethidium bromide.

The primers used for SYBR Green PCR were F3 and B3, and the amplification was performed on an $\mathrm{iQ} 5 \& \mathrm{MYQ}^{\mathrm{TM}}$ Real-Time PCR Detection System (Bio-Rad Laboratories, Hercules, CA). Reactions were carried out in 8-Tube Strips in a $20 \mu \mathrm{L}$ reaction volume containing $10 \mu \mathrm{L}$ iQ5 SYBR Green SuperMix $2 \times$ (Biorad), $300 \mathrm{nM} \mathrm{F}$, $300 \mathrm{nM} \mathrm{B}, 7 \mu \mathrm{L}$ water and $100 \mathrm{ng}$ of template genomic DNA, and was brought up to volume with sterile distilled water. The thermal profile for all SYBR Green PCRs was $95^{\circ} \mathrm{C}$ for $3 \mathrm{~min}$ followed by 40 cycles of $95^{\circ} \mathrm{C}$ for $10 \mathrm{~s}$ and $55^{\circ} \mathrm{C}$ for $30 \mathrm{~s}$. The melting curve was determined by following a further $95^{\circ} \mathrm{C}$ for $1 \mathrm{~min}, 55^{\circ} \mathrm{C}$ for $1 \mathrm{~min}$ and $55-95^{\circ} \mathrm{C}$ for $10 \mathrm{~s}$. In each 8-well tube, the AbHV standard was run parallel with the samples. Each sample was tested in duplicate or triplicate to ensure repeatability.

\subsection{Evaluation of the LAMP assay using field samples}

Six AbHV-infected and five uninfected samples were evaluated in this study. LAMP was carried out using the optimized conditions. Conventional PCR was performed using the 40f/146r primer sets and methods described previously (Chen et al., 2012). All amplification products were electrophoresed on $2 \%(\mathrm{w} / \mathrm{v})$ agarose gels and stained with ethidium bromide. A reaction that included AbHV DNA was used as a positive control and a reaction without a DNA template was the negative control. Ten PCR-negative samples were evaluated by using LAMP and SYBR Green PCR.

\section{Results}

\subsection{Optimization of the AbHV LAMP reaction}

The LAMP reactions were carried out to determine the optimal reaction temperature and time durations. Temperatures of $62{ }^{\circ} \mathrm{C}$, $63^{\circ} \mathrm{C}, 64{ }^{\circ} \mathrm{C}$ and $65^{\circ} \mathrm{C}$ and durations of $15 \mathrm{~min}, 30 \mathrm{~min}, 45 \mathrm{~min}$ and 60 min were tested. It showed that $63^{\circ} \mathrm{C}$ for 60 min was the optimal reaction condition for the AbHV LAMP assay (Fig. 1). The colour of

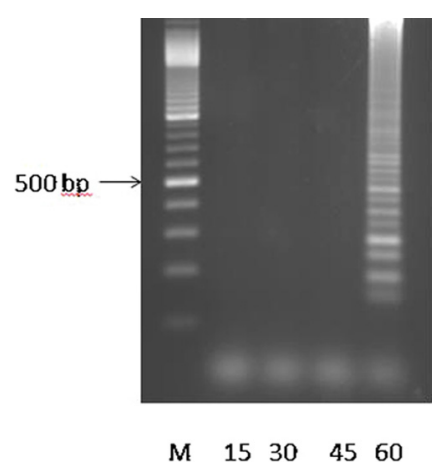

Fig. 1. Determination of LAMP reaction conditions over different reaction durations by agarose gel electrophoresis. Lanes $1-4$, LAMP was carried out for 15, 30, 45 and 60 min at $63^{\circ} \mathrm{C}$, respectively. Lane $\mathrm{M}$, marker.

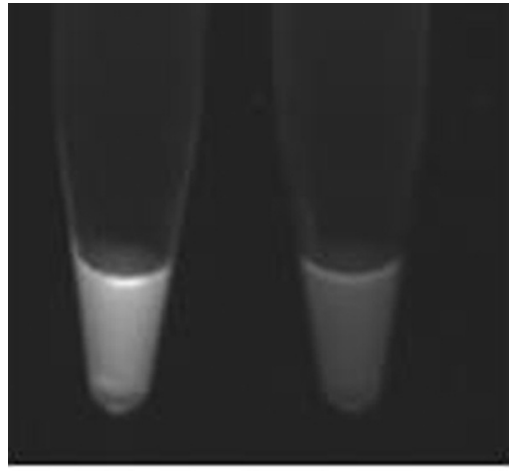

\section{Positive Negative}

Fig. 2. LAMP products detected by visual observation. Positive: positive reaction visualized by UV-light; Negative: negative reaction.

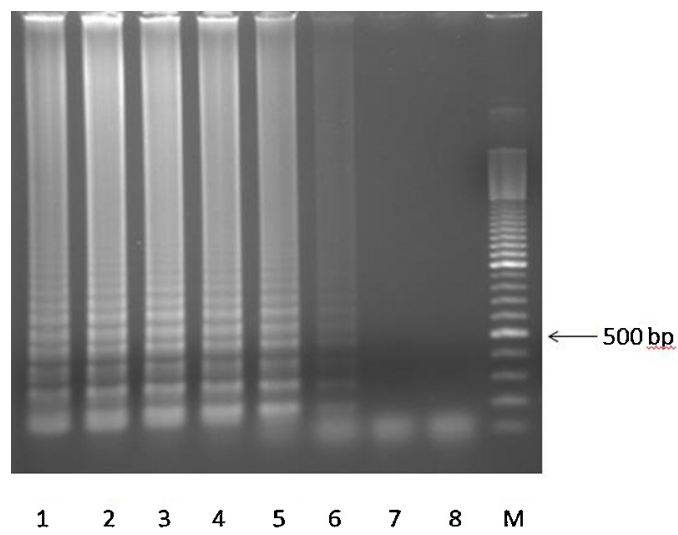

Fig. 3. Sensitivities of LAMP and PCR assays for detection of AbHV. Lanes 1-8, LAMP conducted using 10-fold serial dilutions of plasmid DNA. 1: $2 \times 10^{7}$ copies; $2: 2 \times 10^{6}$ copies; $3: 2 \times 10^{5}$ copies; $4: 2 \times 10^{4}$ copies; $5: 2 \times 10^{3}$ copies; $6: 2 \times 10^{2}$ copies; 7 : $2 \times 100$ copies; M: 100 bp marker.

LAMP products in positive reactions changed to yellowish green, whereas those in negative reactions remained reddish orange. The intensities of the colour changes appeared to be associated with viral loads, wherein more intensive colour changes occurred in samples with higher loads. When visualized under UV transillumination, the positive sample shows a bright green fluorescence compared to the original colour of negative control (Fig. 2).

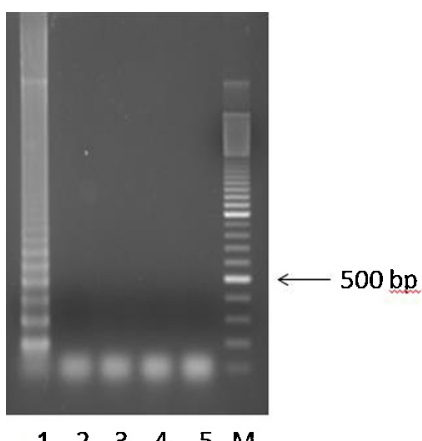

$\begin{array}{llllll}1 & 2 & 3 & 4 & 5 & M\end{array}$

Fig. 4. The PCR detection of AbHV is specific since all negative controls yield negative results. Lane 1, Haliotis herpesvirus (AbHV); lane 2, chicken infectious laryngotracheitis; lane 3, koi herpesvirus; lane 4, eel herpesvirus; lane 5, ostreid herpesvirus (OsHV-1); and lane M: 100 bp DNA. 


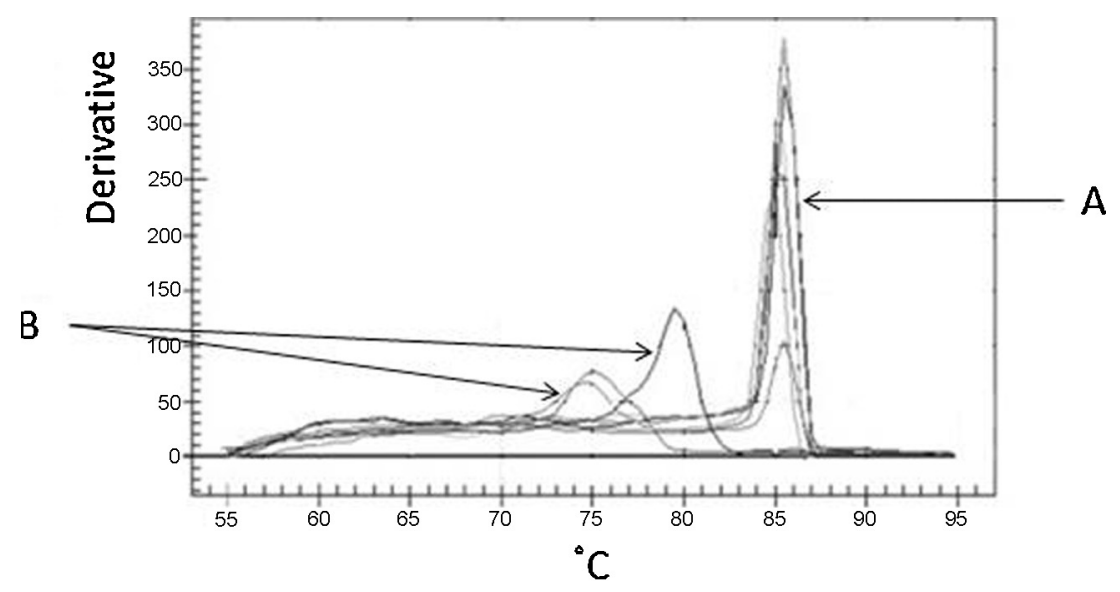

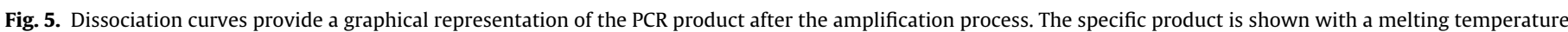
$(\mathrm{Tm})$ of $86^{\circ} \mathrm{C}$, while the primer dimer has a characteristically lower Tm of $75-80^{\circ} \mathrm{C}$. A: melt curve of specific product; B: melt curve of a primer dimer

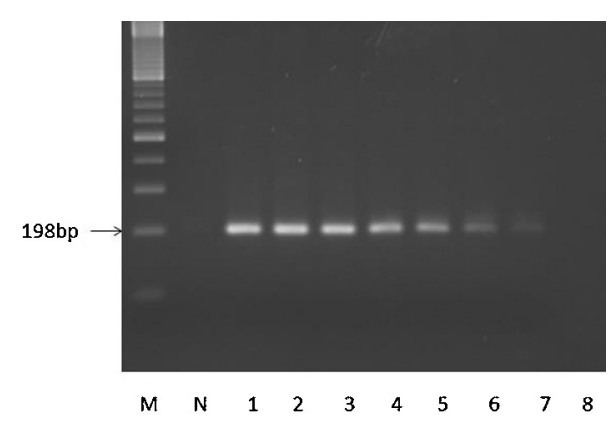

Fig. 6. Confirmed gel electrophoresis amplification of the expected $198 \mathrm{bp}$ fragment for samples containing from $2 \times 10^{7}$ to $2 \times 10^{0}$ copies. $1: 2 \times 10^{7}$ copies; 2 : $2 \times 10^{6}$ copies; 3 : $2 \times 10^{5}$ copies; $4: 2 \times 10^{4}$ copies; 5: $2 \times 10^{3}$ copies; $6: 2 \times 10^{2}$ copies; 7 : $2 \times 100$ copies; M: marker; N: blank control.

\subsection{Sensitivity of LAMP and conventional PCR}

The sensitivities of the LAMP assay and conventional PCR were determined using 10 -fold serial dilutions $\left(2 \times 10^{-1}-2 \times 10^{-8}\right.$ per $\mu \mathrm{L})$ of plasmid DNA as the template. The sensitivity of target plasmid DNA by LAMP assay and conventional PCR was $10^{2}$ copies and $10^{4}$ copies per $\mu \mathrm{L}$ (Fig. 3 ), respectively.

\subsection{Specificity of the LAMP assay}

The specificity of the LAMP assay for the detection of AbHV was performed using DNA from different herpesviruses including OsHV-1, KHV, eel herpesvirus and avian infectious laryngotracheitis virus. No amplicons were obtained from these viral DNAs (Fig. 4) indicating the specificity of the primers and LAMP.

\subsection{SYBR Green PCR}

A preliminary test was carried out to verify the efficiency of the primer set with SYBR Green I chemistry to detect and quantify
AbHV DNA. The primer pair B3/F3 was tested using dilutions of AbHV genomic DNA. Real-time PCR yielded specific amplification, and a single peak was recorded on the melt curve (Fig. 5). The Tm values of the amplified products were systematically monitored in each experiment. The sizes of real-time PCR amplicons were monitored by agarose gel electrophoresis, and bands of the expected size (198 bp) were reported (Fig. 6). To determine the sensitivity of the assay, 10 -fold serial dilutions $\left(2 \times 10^{-1}-2 \times 10^{-8}\right.$ per $\left.\mu \mathrm{L}\right)$ of viral genomic DNA were applied. It was possible to quantify AbHV cloned DNA copy numbers of at least $2 \times 10^{1}$ copies per $\mu \mathrm{L}$ (Fig. 7).

\subsection{Evaluation of the sensitivity of LAMP assay}

LAMP assays were carried out with DNA samples extracted from six AbHV-infected abalone and all six samples were positive for the presence of AbHV. Ten samples collected from farms in southern Taiwan without history of AbHV infection were negative in this assay. Ten field samples with low mortality of abalone were analyzed and none were positive using the regular PCR assay, 40\% (4/10) the LAMP assay and 50\% (5/10) the SYBR Green PCR assay. Results suggested that the LAMP assay was more sensitive than conventional PCR but less sensitive than the SYBR Green PCR assay.

\section{Discussion}

AbHV is the causative agent of a viral disease affecting abalone and has caused high mortality outbreaks in a short period of time among cultured abalone. It is important to have rapid and sensitive detection of this pathogen in the field in order to monitor disease outbreaks and take appropriate measures in a timely manner.

The LAMP assay developed in this study allows the rapid detection of AbHV DNA. The products generated by this method are detectable by visual observation as white precipitates under fluorescent light. In addition, the products generated by this method can be analyzed by agarose gel electrophoresis.

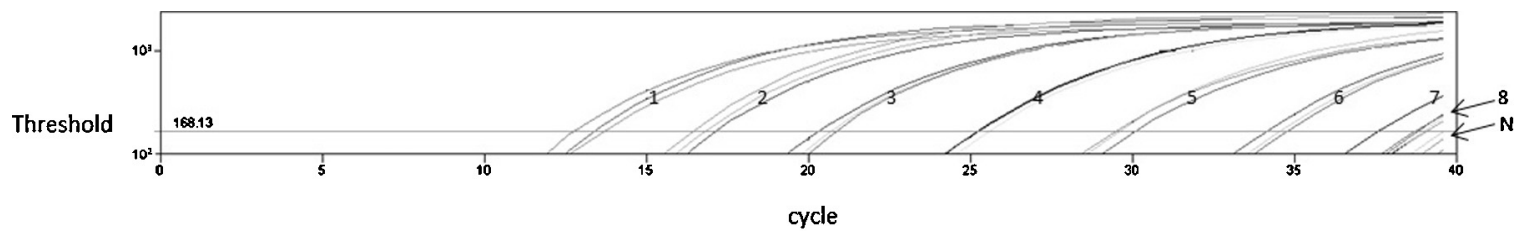

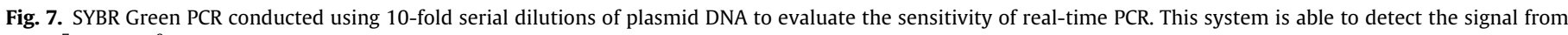
$2 \times 10^{7}$ to $2 \times 10^{0}$ copies. 
Conventional PCR in combination with gene sequencing has long been used to confirm the accuracy of amplicons generated by PCR (Muhling et al., 2006; Victoria et al., 2010). However, this PCR detection procedure requires several hours to be completed. In contrast, DNA detection with the LAMP was at least $2 \mathrm{~h}$ faster than that with conventional PCR. The LAMP assay was also workable over a range of temperatures (from 62 to $65^{\circ} \mathrm{C}$ ), which facilitates its application in the field without precise temperature control.

Furthermore, AbHV DNA could be amplified specifically and sensitively using the LAMP technique. No amplification was observed when the method was used to detect nucleic acids from other herpesviruses including OsHV-1, KHV, eel herpesvirus and an avian herpesvirus. These results indicate the specificity and broad applicability of LAMP for the detection of AbHV DNA in the field.

The LAMP assay appeared to be 100 folds more sensitive than conventional PCR and 10 folds less sensitive than SYBR Green PCR. Corbeil et al. (2010) have developed a TaqMan PCR assay for the Australian abalone herpesvirus. This TaqMan assay detected 30 copies of recombinant plasmid per reaction. The sensitivity of the LAMP assay appears to vary with the herpesvirus species applied. The detection of OsHV-1 is 20 copies per reaction (Ren et al., 2010), 50 copies/tube for human herpesvirus 6 infection (Ihira et al., 2004) and 100 copies/tube for human herpesvirus 8 (Kuhara et al., 2007).

In conclusion, this LAMP method enables the detection of small amounts of AbHV DNA. This method can be used to detect rapidly AbHV with high sensitivity and specificity.

\section{Acknowledgments}

The authors thank Professor FI Wang, Graduate Institute of Molecular and Comparative Pathology, School of Veterinary Medicine, National Taiwan University, Dr. C Wang and Dr. YP Chen, Animal Health Research Institute Taiwan, for technique assistance in this study. The study was supported by a grant from the Council of Agriculture, Taiwan.

\section{References}

Burge, C.A., Strenge, R., Friedman, C.S., 2011. Detection of the oyster herpesvirus in commercial bivalves in northern California, USA: conventional and quantitative PCR. Dis. Aquat. Organ. 94, 107-116.

Caipang, C.M.A., Kulkarni, A., Brinchmann, M.F., Korsnes, K., Kiron, V., 2010. Detection of Francisella piscicida in Atlantic cod (Gadus morhua L.) by the loop-mediated isothermal amplification (LAMP) reaction. Vet. J. 184, 357-361.

Caipang, C.M.A., Haraguchi, I., Ohira, T., Hirono, I., Aoki, T., 2004. Rapid detection of a fish iridovirus using loop-mediated isothermal amplification (LAMP). J. Virol. Methods 121, 155-161

Chang, P.H., Kuo, S.T., Lai, S.H., Yang, H.S., Ting, Y.Y., Hsu, C.L., Chen, H.C., 2005. Herpes-like virus infection causing mortality of cultured abalone Haliotis diversicolor supertexta in Taiwan. Dis. Aquat. Organ. 65, 23-27.

Chen, M.H., Kuo, S.T., Renault, T., Friedman, C.S., Chang, P.H., 2012. Development of a polymerase chain reaction for the detection of abalone herpesvirus infection based on the DNA polymerase gene. J. Virol. Methods 185, 1-6.

Corbeil, S., Colling, A., Williams, L.M., Wong, F.Y., Savin, K., Warner, S., Murdoch, B., Cogan, N.O., Sawbridge, T.I., Fegan, M., Mohammad, I., Sunarto, A., Handlinger, J., Pyecroft, S., Douglas, M., Chang, P.H., Crane, M.S., 2010. Development and validation of a TaqMan ${ }^{\circledR}$ PCR assay for the Australian abalone herpes-like virus. Dis. Aquat. Organ. 92, 1-10.

Farley, C.A., Banfield, W.G., Kasnic G. Jr., Foster, W.S., 1972. Oyster herpes-type virus. Science 178, 759-760.

Gunimaladevi, I., Kono, T., Venugopal, M.N., Sakai, M., 2004. Detection of koi herpesvirus in common carp, Cyprinus carpio L., by loop-mediated isothermal amplification. J. Fish Dis. 27, 583-589.

Gunimaladevi, I., Kono, T., LaPatra, S.E., Sakai, M., 2005. A loop mediated isothermal amplification (LAMP) method for detection of infectious hematopoietic necrosis virus (IHNV) in rainbow trout, Oncorhynchus mykiss. Arch. Virol. 150, 899-909.

Hooper, C., Hardy-Smith, P., Handlinger, J., 2007. Ganglioneuritis causing high mortalities in farmed Australian abalone, Haliotis laevigata and Haliotis rubra. Aust. Vet. J. 85, 188-193.

Ihira, M., Yoshikawa, T., Enomoto, Y., Akimoto, S., Ohashi, M., Suga, S., Nishimura, N., Ozaki, T., Nishiyama, Y., Notomi, T., Ohta, Y., Asano, Y., 2004. Rapid diagnosis of human herpesvirus 6 infection by a novel DNA amplification method, loopmediated isothermal amplification. J. Clin. Microbiol. 42, 140-145.

Kono, T., Savan, R., Sakai, M., Itami, T., 2004. Detection of white spot syndrome virus in shrimp by loop-mediated isothermal amplification. J. Virol. Methods 115, 59-65.

Kuhara, T., Yoshikawa, T., Ihira, M., Watanabe, D., Tamada, Y., Katano, H., Asano, Y., Matsumoto, Y., 2007. Rapid detection of human herpesvirus 8 DNA using loop-mediated isothermal amplification. J. Virol. Methods 144, 79-85.

Maruyama, F., Kenzaka, T., Yamaguchi, N., Tani, K., Nasu, M., 2003. Detection of bacteria carrying the stx2 gene by in situ loop-mediated isothermal amplification. Appl. Environ. Microbiol. 69, 5023-5028

Muhling, J., Raye, W.S., Buddle, J.R., Wilcox, G.E., 2006. Genetic characterisation of Australian strains of porcine circovirus types 1 and 2. Aust. Vet. J. 84, 421-425.

Nakatsugawa, T., Nagai, T., Hiya, K., Nishizawa, T., Muroga, K., 1999. A virus isolated from juvenile Japanese black abalone Nordotis discus discus affected with amyotrophia. Dis. Aquat. Organ. 36, 159-161.

Notomi, T., Okayama, H., Masubuchi, H., Yonekawa, T., Watanabe, K., Amino, N., Hase, T., 2000. Loop-mediated isothermal amplification of DNA. Nucleic Acids Res. 28 (12), e63.

Otsu, R., Sasaki, K., 1997. Virus-like particles detected from juvenile abalones, Nordotis discus discus reared with an epizootic fatal wasting disease. J. Invertebr. Pathol. 70, 167-168

Ren, W., Renault, T., Cai, Y., Wang, C., 2010. Development of a loop-mediated isothermal. amplification assay for rapid and sensitive detection of ostreid herpesvirus 1 DNA. J. Virol. Methods 170, 3036.

Renault, T., 2008. Shellfish Viruses. Encyclopedia of Virology, vol. 5. Elsevier, Oxford, pp. 560-567.

Renault, T., Novoa, B., 2004. Viruses infecting bivalve molluscs. Aquat. Living Resour. 17, 397-409.

Savan, R., Igarashi, A., Matsuoka, S., Sakai, M., 2004. Sensitive and rapid detection of Edwardsiellosis in fish by a loop-mediated isothermal amplification method. Appl. Environ. Microbiol. 70, 621-624.

Soliman, H., El-Matbouli, M., 2005. An inexpensive and rapid diagnostic method of Koi Herpesvirus (KHV) infection by loop-mediated isothermal amplification. Virol. J. 2, 83.

Song, Z.H.R., Ji, R.X., Yan, S.F., Chen, C.S., 2000. A spherovirus resulted in mass mortality of Haliotis diversicolor aquatilis. J. Fish China 24, 463-467.

Victoria, J.G., Wang, C., Jones, M.S., Jaing, C., McLoughlin, K., Gardner, S., Delwart, E.L., 2010. Viral nucleic acids in live-attenuated vaccines: detection of minority variants and an adventitious virus. J. Virol. 84, 6033-6040.

Wang, B., Li, X., 1997. Infection of spherical viruses from Haliotis discus hannai Ino. Virol. Sin. 12, 360-363.

Wang, J.Y., Chen, B.H., Feng, J., Yu, M.Y., 2000. Primary observation of spherical viruses from diversicolor abalone, Haliotis diversicolor Reeve. J. Oceanograph. $12,63-67$.

Weicheng, R., Renault, T., Cai, Y.Y., Wang, C.M., 2010. Development of a loopmediated isothermal amplification assay for rapid and sensitive detection of ostreid herpesvirus 1 DNA. J. Virol. Methods 170, 30-36.

Zhang, Z.H.X., Wang, J., Su, Y.Q., Yan, Q.P., Chi, X.C., Zhou, H.M., Zhou, Y.C., 2001. Pathogeny and histopathology of the epidemic disease in Haliotis diversicolor supertexta. J. Xiamen Univ. 40, 949-956. 